\title{
Measuring the Public Awareness toward Household Waste Management in Muharraq Governorate-Kingdom of Bahrain
}

\author{
S. Y. Abbas' ${ }^{1}$, K. Kirwan ${ }^{2}$, D. Lu ${ }^{3}$ \\ ${ }^{1}$ Sumaya Yusuf Abbas, Department of Natural Recourses \& Environment, Arabian Gulf University, Salmaniya, \\ Manama-Kingdom of Bahrain \\ ${ }^{2}$ Kerry Kirwan, Sustainable Material and Manufacturing Group, WMG, University of Warwick, Coventry, UK \\ ${ }^{3}$ Supply Chain and Logistics, WMG, University of Warwick, Coventry, UK \\ Email: sumayayousif@agu.edu.bh, kerry.kirwan@warwick.ac.uk, D.Lu@warwick.ac.uk
}

How to cite this paper: Abbas, S.Y., Kirwan, K. and Lu, D. (2020) Measuring the Public Awareness toward Household Waste Management in Muharraq Governorate-Kingdom of Bahrain. Journal of Environmental Protection, 11, 196-214. https://doi.org/10.4236/jep.2020.113012

Received: January 14, 2020

Accepted: March 10, 2020

Published: March 13, 2020

Copyright $\odot 2020$ by author(s) and Scientific Research Publishing Inc. This work is licensed under the Creative Commons Attribution International License (CC BY 4.0).

http://creativecommons.org/licenses/by/4.0/

\begin{abstract}
Municipal Solid Waste (MSW) generation is growing rapidly as compared to the rate of urbanization. Household waste management is considered a highly challenging task for Bahrain's policy-makers, urban planners and municipalities due to rising population, burgeoning growth rate of waste generation, limited availability of land and scarce waste disposal sites. Public awareness represents a key enabler in order to succeed any sustainable waste management practice in the country. The survey aimed at gauging public awareness about household waste management in Muharraq Governorate and explored if there are any correlations between educational level, gender, occupation and age and area of living with the level of public awareness as well as its three components: knowledge, attitude and behaviour of the people in $\mathrm{Mu}$ harraq Governorate. The results indicated the total awareness is significantly different across different age levels and nationality. Moreover, it shows a high public awareness toward household waste management among people in Muharraq Governorate, which indicated that the society is aware and has the basics to build on in terms of sustainable waste management practices and technologies adoption, which may help overcome the possible social barrier represented by low public awareness.
\end{abstract}

\section{Keywords}

Public Awareness, Household Waste Management, Attitude, Behaviour, Kingdom of Bahrain, Muharraq Governorate 


\section{Introduction}

The Gulf Co-operation Council (GCC) countries rank among the highest waste generating countries per capita in the world, due to the changes in consumption patterns [1] [2]. The region's total amount of waste ranged from 90 million to 150 million metric tonnes annually, with the United Arab of Emirates (UAE) being the highest generator per capita at approximately $2.2 \mathrm{~kg}$ [3]. The amount of waste generated is likely to increase rapidly to anywhere between 1.5 and 2 times of the existing volume in 2021. The Kingdom of Bahrain forms part of the list of GCC countries. Thus, waste management protocols need to be re-evaluated in order to establish methods that contribute to minimizing greenhouse gas emissions, improving the efficiency of resource management, and designing more eco-friendly management plans in GCC states.

Municipal Solid Waste (MSW) can be identified as: "a waste type that predominantly includes household waste (domestic waste), except industrial and agricultural wastes, with sometimes the addition of commercial wastes collected by a municipality within a given area" [4].

Municipal Solid Waste (MSW) generation is growing rapidly as compared to the rate of urbanization. MSW management is considered a highly challenging task for Bahrain's policy-makers, urban planners and municipalities due to rising population, burgeoning growth rate of waste generation, limited availability of land and scarce waste disposal sites.

It is imperative to focus on the awareness toward the Household Waste (HW) as it represents the majority of MSW composition in the Kingdom of Bahrain, which is dumped into the only MSW landfill (Askar Landfill), which reached its maximum dumping capacity recently.

As public awareness represents a key enabler to successful waste management [5], it signifies the starting point for the fundamental ingredient of a resource-efficient society [6], something that is also deemed as the foundation of public capacity that helps the public initiate steps to succeed in waste management practices across Bahrain, which includes technological adoption of waste management e.g. Incineration and Anaerobic Digestion.

\section{The Study Area: Muharraq Governorate}

The Kingdom of Bahrain is divided into four Governorates (Figure 1): Muharraq, Capital Northern and southern Governorate. Administratively, there is one municipality in each Governorate and each Municipality is responsible for ensuring that waste is collected, streets are clean, and current disposal facilities are operated.

Muharraq is the third largest Governorate in Bahrain, and is situated on $\mathrm{Mu}$ harraq Island. Apart from having a great historical significance, the Bahrain International Airport is also located in the Governorate. Muharraq Island is the third largest island among all islands in Bahrain, following Bahrain Island and Hawar Island. It includes several towns and villages, including Al Muharraq, 

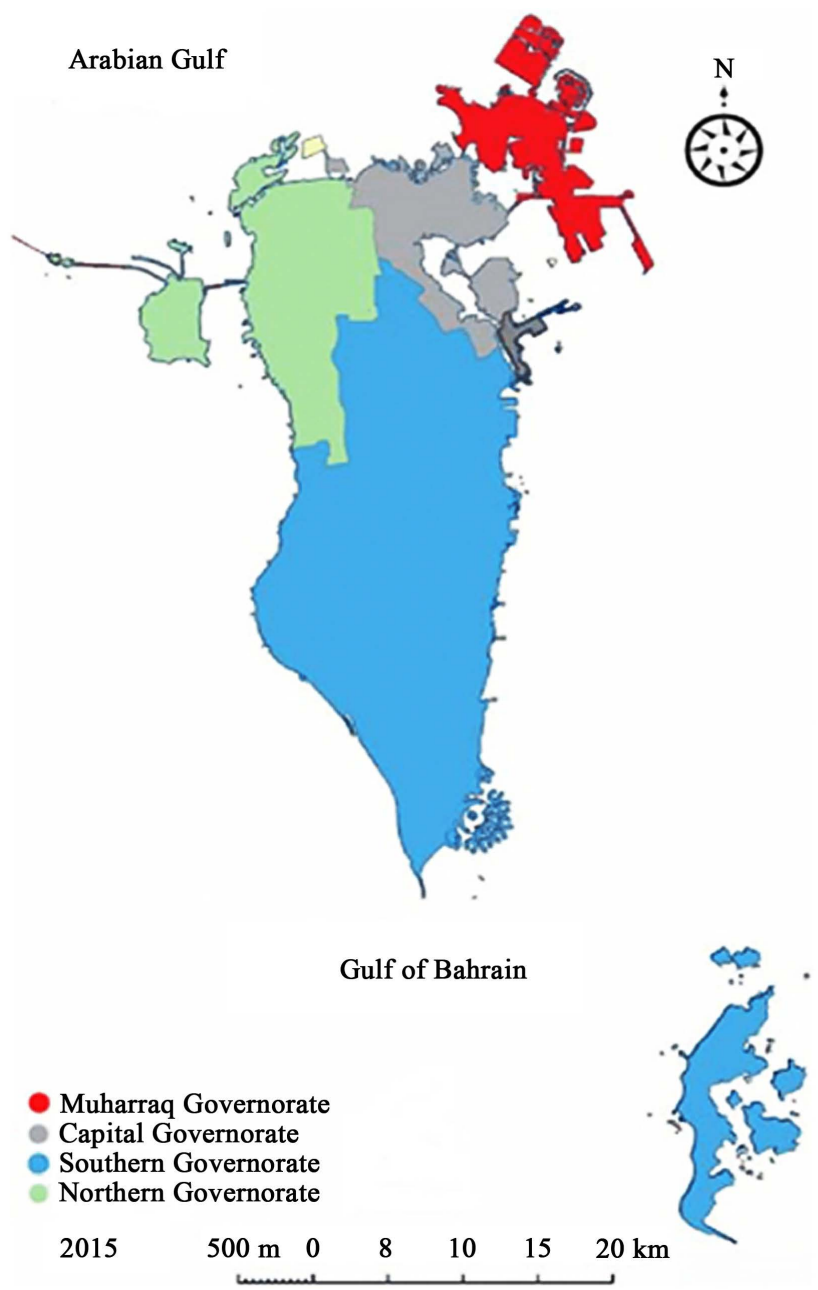

Figure 1. Bahrain map with the main governorates including Muharraq (north), the study area.

Arad, Dair, Busaiteen, Hidd, Halaat, Galali, and Samaheej. In 2017, the total area of Muharraq Governorate reached $64.8 \mathrm{~km}^{2}$, and the population had increased to 298,517 [7].

Against this backdrop, this study undertakes an explanation of the missing value analysis and demographics analysis. To that end, confirmatory factor analysis (CFA) was undertaken for each item of the questionnaire using the AMOS 22. In addition, in order to verify the hypotheses, $t$-test and ANOVA test were performed. The findings are then interpreted by an appropriate use of facts and figures.

\section{Literature Review}

Public awareness is an important tool for increasing public participation in sustainable waste management programs [5]. It is the key to successful waste management [6] and considered a critical component in any waste management program apart from appropriate legislation, strong technical support, and adequate funding. "Involve people in their own community decisions and actions, 
to avoid "not my business"-syndrome, and ensure "maximum participation" [8]. It is useful to raise awareness about the purpose of the separation of food waste before the actual implementation.

Raising awareness about municipal solid waste management is an essential component of effective waste management. Moreover, community participation has a direct effect on efficient solid waste management plan [9].

Paucity of pre-planning, infrastructure, public awareness and many other factors have become the root factors for worsening municipal solid waste management in Pakistan [10]. In addition, public awareness of appropriate solid waste management practices is the starting point and fundamental ingredient of a sound material-cycle and resource-efficient society [11]. Furthermore, it was argued that public awareness is the foundation of public capacity, which enables the public to undertake actual actions of each element of the 3Rs [11]. Consequently, such actions become the input for the advancement or "performance" of 3Rs for a sound material-cycle society. Central and local governments, environmental NGOs, entrepreneurs, and mass-media, influence public awareness through their policies, practices, and operations, which leads to "capacity development".

Public can be defined as "all individuals within society: ordinary citizens, state and municipal government officials, politicians, NGO staff, business executives and employees, including small and medium enterprise (SMEs) owners. In order to discuss "awareness", we cannot exclude any individuals who have opinions on the environment-all opinions count" [11]. In order to define "Public Awareness", it is helpful to define other related terms, which include:

Public Awareness-acquired knowledge and concerns of individuals concerning 3Rs, sustainable production and consumption, and resource efficiency.

Public Knowledge-acquired experience and a basic understanding of individuals concerning 3Rs, sustainable production, and consumption, and resource efficiency.

Public Attitude-acquired values, expression of concern and interests, and motivation of individuals for actions concerning 3Rs, sustainable production and consumption, and resource efficiency.

Public Action-actions were taken by individuals with regard to their behaviours, consumption choices, and lifestyle practices to accommodate or support 3Rs, sustainable production and consumption, and resource efficiency [11].

Different studies have demonstrated the fact that enhancing Public Environmental Awareness will lead to increased public support for environmental protection [12] [13]. Their study entails the development of a questionnaire to investigate current levels of students' awareness by measuring their concerns, knowledge and attitude.

Furthermore, [14] used questionnaire and statistical methods to measure public awareness in China. They argued that public awareness of domestic waste characteristics and management is a prerequisite for domestic waste management plan. Moreover, they found that age and gender had no obvious effects on 
public awareness of domestic waste management. In addition, [14] concluded that improving environmental education, performing demonstration projects, increasing people's income, and attracting young people to participate in domestic waste management are important for enhancing environmental awareness.

\section{Methodology}

A self-administered questionnaire was designed and used to assess the publics' knowledge, attitude, and behaviour towards domestic waste management.

The study instrument (questionnaire) was divided into two main parts: personal profile or background question to obtain demographic characteristics of the surveyed population, such as age, gender, occupation, education, place of residence, etc. [15]; and survey questions, that consist of 38 statements distributed into three divisions. These included "Knowledge" (perception) that was aimed at measuring the knowledge about household waste management and related issues encompassing 10 statements, "Attitude" that aims to measure the attitude as well as trends in household waste management via 16 statements, and "Behaviour" or the practices towards household waste via 12 statements.

Survey instrument consists of multiple choice or closed-end questions to determine feelings or opinions towards certain issues by allowing the respondents to choose an answer from a list of 5 alternative answers, as well as to gauge the intensity of the respondent's feelings towards an issue [15]. The survey was designed in Microsoft Office Word 2013 to be answered as hardcopies only.

The Likert Scale was used to answer the questionnaire's questions using three types of the scale alternatives: for knowledge, "totally true, true, not sure, not true, and not true at all" scale was used; for attitude: "strongly agree, agree, not sure, disagree, and strongly disagree" was used; while for behaviour, the following scale was used: "always, sometimes, not sure, rarely, never"

"Totally true" for the knowledge statements mean that the respondent knows this information very well. In the attitude statements, "strongly agree" mean that they are highly aware and willing to participate and cooperate. Meanwhile "true" means that the respondent does not have completely perception about this point, but knows something about it in parallel, "agree" means that the respondent has the attitude, albeit of a lower level, while in practice statements, "sometimes" means that the respondent sometimes practices this activity.

"Not sure" is a little negative response, which means that the respondent is unsure about the information, about their attitude, and whether they are practicing or willing to practice this activity.

"Not true" means that the respondent does not have the stated information; "disagree," means they lack the attitude and that they are "rarely" practicing this activity.

Finally, "not true at all" reflects a very negative response of the respondent implying that they do not know much about it or are against what is being stated; "strongly disagree" reflects the respondent's strong disagreement about 
the attitude statement, whereas "never" means they are not practicing the stated behaviour at all.

The statements were carefully selected based on previous studies' questionnaires from the literature review and conversations with many experts within the fields, including national environmental activists, and municipality staff, newspapers and official governmental social media reports, which contribute to enriching the researcher's personal experience in this aspect in a way that reflects the needs of the Bahraini society.

The questionnaire was assessed by seven experts from different disciplines, including social studies, environmental studies and engineering, and technology management from the Arabian Gulf University (college of graduate studies).

The questionnaire assessment scale includes: statement suitability and compatibility to the study aim, the statement's contextual spelling and structure, notes per statement, and other suggestions for improvement. This process lasted two weeks from March 15th-30th 2018.

\subsection{Ethical Considerations}

Ethical approval for the study was obtained from the Biomedical and Scientific Research Ethics Sub-Committee (BSREC) from the University of Warwick, and the Arabian Gulf University.

\subsection{Validity and Reliability}

\subsubsection{Validity}

1) Face validity: For establishing facial validity, the final form of the tool was shown to seven experts (university professors) to seek their responses regarding content, format and language of the tool. All the experts were satisfied with the language and format of the questionnaire to ensure the scale's face validity.

2) Content Validity: At the stage of questionnaire planning, 38 statements were used to measure the level of awareness toward household waste management. Experts reviewed all the 38 items, which means that the final form of the tool evenly represented the contents.

\subsubsection{Reliability}

The tool's reliability was determined using the test-retest method. The same tool was administered to a group of 40 participants (family members, neighbours, and friends) twice at an interval of one week, and the two sets of scores were correlated to obtain a correlation coefficient, which was the index of reliability. The pilot study is described in details below:

\subsection{The Pilot Study}

According to [15], the selected survey firm should conduct a pre-test (pilot study) of the questionnaire. This exercise should be conducted among the survey target group of public. This stage of research will enable the researcher to determine the strength as well as weaknesses of the survey questionnaire about its re- 
liability and validity. Moreover, such a procedure will also reveal unanticipated problems with question wording, format, instructions to skip questions, and thus make sure that respondents understand the questions and providing useful answers [15].

The questionnaires were collected to be analysed using IBM SPSS Statistics Version 23 (2015) software to identify the points of weakness. The same groups were given the same questionnaire to answer after one week, in order to measure the stability and reliability by repeating. Pearson Correlation Coefficient was calculated using SPSS, a measure of the strength of a linear association between two variables and is denoted by $\mathrm{r}$. It indicates how far away all these data points are to this line of best fit and can accommodate a range of values from +1 to -1 . The closer the value of $r$ is to +1 , the stronger the linear relationship.

The Pearson correlation was found to be equal to 0.94 and indicates that the two variables being compared (the total answers of 40 people before and their answers after one week) have a perfect positive relationship with high similarities. The result is shown below in Table 1.

For further confirmation, in order to measure the consistency of the statements as groups in the questionnaire, one more factor was considered. Cronbach's alpha is a measure of internal consistency, that is, how closely related a set of items are as a group. It is considered as a measure of scale reliability. A "high" value for alpha does not imply that the measure is uni-dimensional. The alpha coefficient for 38 questionnaire statements was calculated using SPSS and it was found to be equal to 0.813 .

\section{Analysis of the Questionnaires Data}

SPSS statistical program was primarily used for analyzing questionnaire data, including ANOVA (analysis of variance) and t-test which were used to undertake statistical analyses to highlight significant statistical relationships between variables. Descriptive statistics by frequency was also used to determine the percentage of respondents who agreed and strongly agreed or disagreed/strongly disagreed with some statements of high importance for the Bahraini society e.g. percentage of people who supported the establishment of an incinerator to treat their waste.

Table 1. Result of pilot study for reliability: the Pearson correlation coefficient.

\begin{tabular}{|c|c|c|c|}
\hline & & Total 1 & Total 2 \\
\hline \multirow{3}{*}{ Total 1} & Pearson Correlation & 1 & $0.945^{\star *}$ \\
\hline & Sig. (2-tailed) & & 0.000 \\
\hline & $\mathrm{N}$ & 40 & 40 \\
\hline \multirow{3}{*}{ Total 2} & Pearson Correlation & $0.945^{\star *}$ & 1 \\
\hline & Sig. (2-tailed) & 0.000 & \\
\hline & $\mathrm{N}$ & 40 & 40 \\
\hline
\end{tabular}

**. Correlation is significant at the 0.01 level (2-tailed). 


\subsection{Pilot Testing Results}

The pilot testing was performed to validate the reliability of the survey. Data were collected from 40 respondents and preliminary analysis was performed. As part of this preliminary analysis, reliability analysis and confirmatory factor analysis were also performed. The reliability coefficient of 0.70 or higher is deemed "acceptable" in the majority of social science research scenarios. The overall reliability coefficient was found to be above 0.7 , which indicates the questionnaire is indeed reliable. In addition, the factor loading was measured per item; the results showed many items of knowledge, attitude and behaviour with factor loadings of less than 0.50 . The results of pilot testing are available in Tables 2-4.

\subsection{Demographics Analysis}

The demographics analysis of these respondents is very helpful in studying the characteristics of the sample. The results indicated that among the 300 respondents $(\mathrm{n}=300), \mathrm{n}=65(21.7 \%)$ belonged to age group of $18-20$ years, $\mathrm{n}=50$ (16.7\%) were $21-30$ years, $\mathrm{n}=86(28.7 \%)$ were in $31-40$ age group, $\mathrm{n}=67$ (22.3\%) were aged from $41-50$ years, $\mathrm{n}=26(8.7 \%)$ respondents belonged to the age groups of $51-60$ years and remaining $\mathrm{n}=6(2.0 \%)$ respondents were more than 60 years old. Table 5 illustrates the classification of Age, Gender, Education and Marital Status of the respondents.

Table 2. Pilot testing results of knowledge about household waste management and related issues.

\begin{tabular}{|c|c|c|c|}
\hline $\begin{array}{l}\text { Dimensions of } \\
\text { Awareness }\end{array}$ & Question Items & Estimate & $\alpha$ \\
\hline \multirow{10}{*}{$\begin{array}{c}\text { Knowledge about } \\
\text { the household } \\
\text { waste } \\
\text { management } \\
\text { and related issues }\end{array}$} & $\begin{array}{l}\text { I know where domestic waste is taken daily } \\
\text { and how it is disposed of }\end{array}$ & 0.433 & \multirow{10}{*}{0.700} \\
\hline & $\begin{array}{l}\text { I understand the environmental and health } \\
\text { damage caused by dumping household waste }\end{array}$ & 0.300 & \\
\hline & $\begin{array}{l}\text { Sorting waste components by type at home } \\
\text { (glass, plastic, food, paper, etc.) is paramount } \\
\text { to take advantage of it }\end{array}$ & 0.320 & \\
\hline & $\begin{array}{l}\text { I know the fine of throwing of waste in areas } \\
\text { other than their designated places }\end{array}$ & 0.310 & \\
\hline & $\begin{array}{l}\text { I know who is responsible for collecting and } \\
\text { disposing of household waste }\end{array}$ & 0.400 & \\
\hline & $\begin{array}{l}\text { Burning household waste in a modern and safe } \\
\text { facility is a very effective way of lowering } \\
\text { its size and taking advantage of it }\end{array}$ & 0.710 & \\
\hline & I know the meaning of waste recycling & 0.740 & \\
\hline & Household waste can be used as a source of energy & 0.032 & \\
\hline & Some food waste can be converted into compost & 0.650 & \\
\hline & I know what environmentally friendly products mean & 0.401 & \\
\hline
\end{tabular}


Table 3. Pilot testing results of attitude toward the waste management.

\begin{tabular}{|c|c|c|c|}
\hline $\begin{array}{l}\text { Dimensions of } \\
\text { Awareness }\end{array}$ & Question Items & Estimate & $a$ \\
\hline \multirow{16}{*}{$\begin{array}{l}\text { Attitude about } \\
\text { household } \\
\text { waste } \\
\text { management } \\
\text { and related issues }\end{array}$} & $\begin{array}{l}\text { I am ready to separate waste in separate containers } \\
\text { by type in case the municipalities asked me to do so }\end{array}$ & 0.544 & \\
\hline & $\begin{array}{l}\text { I am satisfied with how domestic waste collection } \\
\text { is currently collected. }\end{array}$ & 0.300 & \\
\hline & $\begin{array}{l}\text { I am satisfied with how domestic waste is } \\
\text { currently disposed }\end{array}$ & 0.333 & \\
\hline & $\begin{array}{l}\text { Responsibility of waste management is a } \\
\text { fundamental partnership between every individual } \\
\text { in society as well as relevant institutions }\end{array}$ & 0.710 & \\
\hline & $\begin{array}{l}\text { I am throwing fines on dumping waste in areas } \\
\text { other than the designated ones }\end{array}$ & 0.205 & \\
\hline & $\begin{array}{l}\text { I am willing to pay extra fees in exchange for the } \\
\text { municipality to distribute coloured containers for } \\
\text { the purpose of sorting household waste }\end{array}$ & 0.230 & \\
\hline & $\begin{array}{l}\text { Curricula should be used at all levels to } \\
\text { promulgate environmental awareness concerning } \\
\text { the significance of household waste management } \\
\text { within the community }\end{array}$ & 0.500 & \\
\hline & $\begin{array}{l}\text { Media and social communication should be } \\
\text { leveraged to spread environmental awareness about } \\
\text { household waste management in the community }\end{array}$ & 0.361 & \multirow[t]{9}{*}{0.700} \\
\hline & $\begin{array}{l}\text { I think giving rewards and incentives to people } \\
\text { for recycling some of their household waste helps } \\
\text { reduce them }\end{array}$ & 0.202 & \\
\hline & $\begin{array}{l}\text { I am ready to cooperate with municipalities } \\
\text { regarding the implementation of a national plan } \\
\text { for the management of household waste }\end{array}$ & 0.344 & \\
\hline & $\begin{array}{l}\text { I prefer buying environmentally friendly goods on } \\
\text { other goods if available }\end{array}$ & 0.452 & \\
\hline & $\begin{array}{l}\text { Disposal of waste in environmentally friendly } \\
\text { ways contributes to highlighting the beautiful } \\
\text { image of the country and revitalizing tourism }\end{array}$ & 0.441 & \\
\hline & $\begin{array}{l}\text { I think that the containers currently used to } \\
\text { collect waste outside the houses are feasible }\end{array}$ & 0.050 & \\
\hline & $\begin{array}{l}\text { I think it is necessary to provide residents and } \\
\text { citizens with information pertaining to household } \\
\text { waste and the proportion of each type }\end{array}$ & 0.800 & \\
\hline & $\begin{array}{l}\text { The contribution of community members to } \\
\text { voluntary clean-up campaigns is civilized }\end{array}$ & 0.400 & \\
\hline & $\begin{array}{l}\text { The issue of household waste management assumes } \\
\text { significance for me }\end{array}$ & 0.360 & \\
\hline
\end{tabular}

The data were collected from the respondents of different nationalities. Twenty-nine (9.7\%) respondents were residence whereas there were 271 (90.3\%) respondents Bahraini citizens. In residential area classification, majority of 
Table 4. Pilot testing results of behaviour of waste management.

\begin{tabular}{|c|c|c|c|}
\hline $\begin{array}{l}\text { Dimensions of } \\
\text { Awareness }\end{array}$ & Question Items & Estimate & $\alpha$ \\
\hline \multirow{12}{*}{$\begin{array}{c}\text { Action and } \\
\text { Behaviour of } \\
\text { household waste } \\
\text { management } \\
\text { and related issues }\end{array}$} & $\begin{array}{l}\text { I am keen to watch documentaries on } \\
\text { environmental issues }\end{array}$ & 0.600 & \multirow{12}{*}{0.800} \\
\hline & $\begin{array}{l}\text { I am careful to guide others to throw the waste } \\
\text { in the allocated places only and not the street }\end{array}$ & 0.100 & \\
\hline & $\begin{array}{l}\text { I am currently separating household waste } \\
\text { components into special containers or bags at } \\
\text { home (food, plastic, glass, paper, ...) }\end{array}$ & 0.700 & \\
\hline & I use some of my food waste to feed animals or fish & 0.400 & \\
\hline & $\begin{array}{l}\text { I use some food waste by turning it into fertilizer } \\
\text { for agriculture }\end{array}$ & 0.800 & \\
\hline & $\begin{array}{l}\text { I reuse some household waste components } \\
\text { (empty plastic cans, bottles, etc.) in useful things }\end{array}$ & 0.421 & \\
\hline & $\begin{array}{l}\text { When I go on a trip to parks and other public } \\
\text { places, I make it a point to remove all the waste } \\
\text { before leaving the place and put it in the } \\
\text { allocated containers }\end{array}$ & -0.024 & \\
\hline & $\begin{array}{l}\text { Be sure to attend and participate in } \\
\text { environmental-related events } \\
\text { (seminars, workshops, courses, lectures ...) }\end{array}$ & 0.634 & \\
\hline & $\begin{array}{l}\text { I encourage others to reuse some of the household } \\
\text { waste components to take advantage of them }\end{array}$ & 0.715 & \\
\hline & $\begin{array}{l}\text { I buy environmentally friendly products (such as } \\
\text { reusable water bottles instead of plastic containers) }\end{array}$ & 0.700 & \\
\hline & $\begin{array}{l}\text { Make sure to remove the waste bags from my } \\
\text { house daily at a specific time }\end{array}$ & 0.371 & \\
\hline & $\begin{array}{l}\text { I put the waste bags inside the containers and } \\
\text { not outside when taking them out of the house }\end{array}$ & 0.193 & \\
\hline
\end{tabular}

Table 5. Age, gender, education and marital status classification.

\begin{tabular}{|c|c|c|c|c|}
\hline Variable & Group & Frequency & Percent & Cumulative Percent \\
\hline \multirow[t]{6}{*}{ Age } & $18-20$ & 65 & 21.7 & 21.7 \\
\hline & $21-30$ & 50 & 16.7 & 38.3 \\
\hline & $31-40$ & 86 & 28.7 & 67.0 \\
\hline & $41-50$ & 67 & 22.3 & 89.3 \\
\hline & $51-60$ & 26 & 8.7 & 98.0 \\
\hline & 61 and above & 6 & 2.0 & 100.0 \\
\hline \multirow[t]{2}{*}{ Gender } & Male & 94 & 31.3 & 31.3 \\
\hline & Female & 206 & 68.7 & 100.0 \\
\hline \multirow[t]{4}{*}{ Education } & Intermediate School and Below & 15 & 5.0 & 5.0 \\
\hline & Secondary School & 94 & 31.3 & 36.3 \\
\hline & Undergraduate Degree & 164 & 54.7 & 91.0 \\
\hline & Higher Education & 27 & 9.0 & 100.0 \\
\hline \multirow[t]{3}{*}{ Marital Status } & Single & 95 & 31.7 & 31.7 \\
\hline & Married & 192 & 64.0 & 95.7 \\
\hline & Others & 13 & 4.3 & 100.0 \\
\hline Total & & 300 & 100 & 100 \\
\hline
\end{tabular}


respondents were found to belong to the area of Hidd (21\%) Arad (18\%), Busaiteen (18.7\%); the rest belonged to Halat (1\%), Samaheej (6\%) and others (7\%).

According to the results, in education classification, the majority of respondents had undergraduate degree $(54.7 \%)$, whereas $n=94$ (31.3\%) participants had attended secondary school; $\mathrm{n}=27$ (9\%) had higher education whereas $\mathrm{n}=$ $15(5.0 \%)$ respondents belonged to the intermediate and below group.

In marital status classification, the majority of respondents were married $(64 \%)$ and the rest were $31.7 \%(n=95)$ single; 13 were included in others' group.

\subsection{Confirmatory Factor Analysis}

After obtaining the data of 300 respondents, the researcher performed the confirmatory factor analysis (CFA) to establish the dimensionality of the questionnaire. The results indicated that there are three dimensions of the overall awareness of respondents about household waste management.

Given that the factor loading is acceptable if it was greater than 0.5 , the results indicated four items whose factor loading is higher than 0.50 , whereas there are six items of Knowledge with factor loadings of less than 0.50 . In this regard, [16] recommended that the items having factor loadings of lower than 0.50 should be deleted from the list and that the final analysis should be performed on items which have loadings greater than 0.50 .

In the dimension of Attitude and trend in household waste management, 9 items have factor loadings of greater than 0.50 whereas 6 items have factor loadings lower than 0.50. In this case, these items needed to be deleted. Table 6 shows the Attitude and trends in household waste management.

\section{Discussion}

The questionnaire included a Likert scale of 5 responses in the analysis; the two positive and two negative answers were combined to be considered as one to have a scale of three results: agree, neutral and disagree generally. For Knowledge, the results indicated that the majority $(64.3 \%)$ of respondents knew who is responsible for collecting and disposing of household waste in Bahrain, and $76.9 \%$ of the respondents believed that household waste can be used as an energy source. Similarly, $87 \%$ and $83 \%$ of respondents recognized that some food waste can be converted into compost, and knew what environmentally friendly products means. The results indicate that there is a high level of knowledge among people and most of them knew the basics of household waste management. People also answered other questions under Knowledge, but these questions were excluded due to the low factor loading (below 0.5) according to the confirmatory factor analysis. For example, 67.9\% knew where domestic waste is taken daily and how it disposed of. Similarly, $85.6 \%$ understood the magnitude of environmental and health damage caused by the dumping of household waste, and $76.7 \%$ agreed that the sorting of waste components by type at home (glass, plastic, food, paper, etc.) is very important. Meanwhile 59.4\% of 
Table 6. Attitude and trends in household waste management.

\begin{tabular}{|c|c|c|}
\hline $\begin{array}{l}\text { Dimension of } \\
\text { Awareness }\end{array}$ & Question Items & Estimate \\
\hline \multirow{16}{*}{$\begin{array}{l}\text { Attitude and } \\
\text { trends in } \\
\text { household } \\
\text { waste } \\
\text { management }\end{array}$} & $\begin{array}{l}\text { I am ready to separate the waste in the house in separate } \\
\text { containers by type if the municipalities ask me to do so }\end{array}$ & 0.522 \\
\hline & I am satisfied with how domestic waste is currently collected. & 0.113 \\
\hline & I am satisfied with how domestic waste is currently disposed. & 0.127 \\
\hline & $\begin{array}{l}\text { Responsibility for waste management is a fundamental partnership } \\
\text { between every individual in the society and relevant institutions }\end{array}$ & 0.543 \\
\hline & $\begin{array}{l}\text { I am imposing fines on dumping waste in areas other } \\
\text { than the designated ones }\end{array}$ & 0.409 \\
\hline & $\begin{array}{l}\text { I am willing to pay extra municipal fees to have the municipality } \\
\text { distribute coloured containers for sorting household waste }\end{array}$ & 0.297 \\
\hline & $\begin{array}{l}\text { Curricula should be used at all levels to promote environmental } \\
\text { awareness about the importance of household waste } \\
\text { management within the community }\end{array}$ & 0.501 \\
\hline & $\begin{array}{l}\text { Media and social communication should be used to spread } \\
\text { environmental awareness about household waste } \\
\text { management in the community }\end{array}$ & 0.554 \\
\hline & $\begin{array}{l}\text { I think giving incentives and rewards to people for recycling } \\
\text { some of their household waste helps reduce them }\end{array}$ & 0.503 \\
\hline & $\begin{array}{l}\text { I am ready to cooperate with municipalities regarding the } \\
\text { implementation of a national plan to better manage } \\
\text { household waste }\end{array}$ & 0.564 \\
\hline & $\begin{array}{l}\text { I prefer buying environmentally friendly goods over } \\
\text { other goods, if available }\end{array}$ & 0.473 \\
\hline & $\begin{array}{l}\text { Disposal of waste in environmentally friendly ways } \\
\text { contributes to enhancement of the beautiful image } \\
\text { of the country and revitalizing tourism }\end{array}$ & 0.380 \\
\hline & $\begin{array}{l}\text { I think the containers presently used to collect waste } \\
\text { outside the houses are suitable }\end{array}$ & 0.067 \\
\hline & $\begin{array}{l}\text { I think it is necessary to provide citizens and residents } \\
\text { with appropriate information on household waste and } \\
\text { the proportion of each type }\end{array}$ & 0.577 \\
\hline & $\begin{array}{l}\text { The contribution of community members to voluntary } \\
\text { clean-up campaigns is civilized }\end{array}$ & 0.559 \\
\hline & $\begin{array}{l}\text { The issue of household waste management assumes } \\
\text { significance to me }\end{array}$ & 0.550 \\
\hline
\end{tabular}

the respondents were aware of the fine imposition of throwing waste in places other than their designated places. When asked if burning household waste in a modern and safe facility is a very effective way of reducing its size, only $48.1 \%$ agreed, whereas $28.1 \%$ were neutral (not sure), and $23.7 \%$ disagreed. A large percentage $(90.3 \%)$ was aware of the meaning of waste recycling.

Regarding Attitude, $90.8 \%$ believed that responsibility for waste management is a fundamental partnership between every individual in society and relevant 
institutions. Moreover, $98 \%$ of respondents opined that media and social communication must be used to spread environmental awareness about household waste management in the community, which is a high percentage that reflects a high level of awareness, whereas $90.6 \%$ opined that giving incentives and rewards to people to recycle some of their household waste helps reduce them. When asked if it is necessary to provide citizens and residents with information on household waste and the proportion of each type, $90.9 \%$ answered with acceptance, and $93 \%$ opined that the contribution of community members to voluntary clean-up campaigns is a civilized behaviour. When asked whether the issue of household waste management assumes importance for them, $83.3 \%$ agreed. Notably, $87.8 \%$ of respondents are in favour of imposing fines on dumping waste in places other than the designated ones, while only $48.3 \%$ are willing to pay extra municipal fees in exchange for the municipality to distribute coloured containers for sorting household waste.

In terms of Behaviour and Practice, $63.9 \%$ are keen to watch documentaries on environmental issues, and $44.8 \%$ of them are currently separating household waste components into special containers or bags domestically (food, plastic, glass, paper, etc.). Additionally, $27.5 \%$ are using some food waste by turning it into fertilizer for agriculture, when asked if they are being sure to attend and participate in related environmental events (seminars, workshops, courses, lectures ...), only $37.2 \%$ did. In addition, $62.5 \%$ always or at least sometimes encourage others to reuse some of their household waste components, and $67.4 \%$ buy environmentally friendly products (such as reusable water bottles instead of plastic containers). Results also show that $89.3 \%$ of the respondents make sure to remove the waste bags from their houses at a specific time daily, while $83.3 \%$ put the waste bags inside the containers and not outside when taking them out of house.

\subsection{Analysis of Individuals Knowledge in Household Waste Management}

To perform the analysis on the knowledge dimension in household management, this research used items having higher than 0.50 loading; four items of knowledge were used to aggregate the score of knowledge dimension. In order to compare the knowledge of household waste management, the One Way ANOVA and Dunnt T3 test was applied for post hoc analysis.

\subsubsection{Comparisons of Individuals' Knowledge of Household Waste Management in Different Age Groups}

The findings revealed a significant difference in all age groups in their knowledge of household waste management $(\mathrm{p}<0.05)$. Post hoc analysis showed a knowledge difference among the younger (18 - 20 Years) and an older age group people (41 - 50 Years) in that older people had a higher knowledge than the younger group. This can be justified by life style differences between the two groups, given that the younger group mostly comprises of students and expe- 
rience is obtained by older group apart from the difference of interests, as well as the sense of responsibility of older people to learn about waste management that they might deal with on a daily basis and not by the younger ones.

\subsubsection{Comparisons of Individuals' Knowledge of Household Waste Management in Different Genders}

In order to perform this analysis, I performed Independent Sample t-test. The results showed a significant difference across male and female in their knowledge of household waste management $(\mathrm{p}<0.05)$.

These findings were found to be inconsistent with that of [17], who observed that females reported more favourable and appreciative attitudes towards the environment in that males were also more concerned with mastering the environment whereas females adopted a more emotional and nurturing approach. Female students also demonstrated greater environmental responsibility (e.g., recycling) than their male counterparts.

\subsubsection{Comparisons of Individuals' Knowledge of Household Waste Management in Different Educational Groups}

In order to determine the difference between the individuals' knowledge of household waste management across the respondents' educational levels the One Way ANOVA Test was performed. The results did not reveal any significant difference in the knowledge of individuals, regardless of their education level ( $\mathrm{p}$ $<0.05)$.

\subsubsection{Comparisons of Individuals' Knowledge of Household Waste Management According to the Marital Status}

The comparison of individuals about their knowledge of household waste management in accordance with their marital status helps to understand the phenomena of household waste management. The One Way ANOVA did not find any significant difference between the single married and other people related to their knowledge about household waste management.

\subsection{Analysis of Individuals Attitude toward Household Waste Management}

The attitude of individuals toward household waste management was also analysed from the perspective of their different demographics. Nine items having factor loadings of greater than 0.50 were used. The aggregate score was used to perform further analysis. As was the case in a previous analysis, this study also performed the independent Sample T Test along with One Way ANOVA.

\subsubsection{Comparison of Attitude toward Household Waste Management at Different Age Levels}

In order to compare the attitude of individuals toward household waste management, this study applied the One Way ANOVA and Dunnt T3 test for post hoc analysis. According to the findings, there is a significant difference among all age groups in their attitude toward household waste management $(\mathrm{p}<0.05)$. 
In addition, difference was found, through post hoc analysis, among the individuals of 21 - 30 years and old age group people (41 - 50 Years). The age group of 41 - 50 exhibited a higher positive attitude to household waste management as opposed to the age group of 21 - 30. This can again be attributed to their experience, maturity, social culture and lifestyle. In addition to higher knowledge, this age group (41 - 50 years) showed a high attitude, which indicates their higher level of public awareness with regard to household management in Muharraq.

\subsubsection{Comparisons of Individuals' Attitude toward Household Waste Management in Different Educational Groups}

To determine the difference between the individuals' attitude toward household waste management regardless of the respondents' educational levels, One Way ANOVA Test was performed. According to the results, no significant difference was found in the attitude of individuals who are high or low in their education $(\mathrm{p}>0.05)$.

\subsubsection{Comparisons of Individuals' Attitude toward Household Waste Management According to the Marital Status}

The comparison of individuals about their attitude to household waste management as per their marital status helps to better understand the phenomena of household waste management. The One Way ANOVA found significant differences between single, married and other people about their attitude towards household waste management. Married people were shown to have a higher positive attitude than single people). This can be justified by the higher sense of responsibility that married people may have as compared to singles; cultural factors tend to make married people more adept at handling the responsibility of family waste management and underpin the need to become more aware of the importance of reusing and recycling waste items in a manner that benefits the country.

\subsection{Analysis of Individuals Behaviour in Household Waste Management}

In order to perform the analysis on the action and behavioural dimension of household management, this research used items with factor loadings of over 0.50 . Only 66 of the 12 items could qualify for the final analysis. To compare the action and behaviour regarding household waste management, this study applied the One Way ANOVA and Dunnt T3 test for post hoc analysis.

\subsubsection{Comparison of Action and Behaviour Related to Household Waste Management at Different Age Levels}

To begin with, the analysis on the age levels was performed. The results revealed a significant difference among all age groups in their actions and behaviour pertaining to house waste management $(\mathrm{p}<0.05)$. In addition, the post hoc analysis found significant behavioural differences among the younger (18 - 20 Years) and adults age group people ( 21 - 30 Years) in that the younger (mostly students) people have higher positive behaviour toward household waste management is- 
sues, probably due to their commitment toward their school or university, their interest, and social culture. Moreover, another significant difference appeared between ( 21 - 30 years) and (41 - 50 years), which shows that the older group has a higher positive behaviour as compared to the younger one.

\subsubsection{Comparisons of Individuals' Action and Behaviour Related to Household Waste Management in Different Genders}

Independent Sample $\mathrm{T}$ Test was used to perform this analysis. The results did not reveal any significant difference across male and female in their behaviour pertaining to household waste management $(\mathrm{p}>0.05)$.

\subsubsection{Comparisons of Individuals' Action and Behaviour of Household Waste Management in Different Educational Groups}

One Way ANOVA Test was performed to determine the difference between the individuals' behaviour of household waste management across the educational level. The findings did not reveal any significant difference in the behaviour of individuals regardless of their education level $(p>0.05)$.

\subsubsection{Comparisons of Individuals Actions and Behaviour Related to Household Waste Management According to the Marital Status}

The comparison of individuals about their behaviour towards household waste management based on their marital status helps to decipher the phenomena of household waste management. The One Way ANOVA did not find any significant difference between single, married and other people in terms of their behaviour related to household waste management.

\section{Conclusions}

In conclusion, this study analyzed the individuals' total awareness about the household waste management in Muharraq Governorate. Using existing literature and advanced statistical analysis, the total awareness was classified in three dimensions such as Knowledge, Attitude and Behaviour about the total awareness of household waste management. The findings established the validity of these dimensions via confirmatory factor analysis. In addition, these dimensions were analyzed across different genders, age, educational levels, etc. The results indicated that the Total Awareness (sum of KAP) is significantly different across different age levels and nationality. In addition, it also exhibits a high level of public awareness toward household waste management among people in the Muharraq Governorate, which indicated that the society has the basics for enabling sustainable waste management practices, which may help everyone to overcome the possible social barrier represented by low public awareness. The results indicate that there is a high level of knowledge among people and most of them knew the basics of household waste management. The results indicated that the majority (64.3\%) of respondents knew who is responsible for collecting and disposing of household waste in Bahrain, and $76.9 \%$ of the respondents believed that household waste could be used as an energy source. Similarly, $87 \%$ 
and $83 \%$ of respondents recognized that some food waste can be converted into compost, and knew what environmentally friendly products means. When asked if burning household waste in a modern and safe facility is a very effective way of reducing its size, only $48.1 \%$ agreed, whereas $28.1 \%$ were neutral (not sure), and $23.7 \%$ disagreed. A large percentage $(90.3 \%)$ was aware of the meaning of waste recycling.

Regarding attitude, $78.6 \%$ of respondents expressed their willingness to separate domestic waste in separate containers by type if the municipalities asked them to do so, which is a positive indicator of people's attitude and reflects their cooperation for any further segregation practices. Moreover, 90.8\% believed that responsibility for waste management is a fundamental partnership between every individual in society and relevant institutions. In addition, $98 \%$ of respondents opined that media and social communication must be used to spread environmental awareness about household waste management in the community, which is a high percentage that reflects a high level of awareness. In addition, 90.6\% opined that giving incentives and rewards to people to recycle some of their household waste helps reduce them, whereas $82.2 \%$ said they are ready to cooperate with municipalities regarding the implementation of a national plan for the management of household waste. While a high percentage of People in Muharraq Governorate (65.2\%) are reusing some of the household waste components (empty plastic cans, bottles, etc.) in useful things and using some of their food waste to feed animals or fish (72.3\%).

Furthermore, males tended to have a better knowledge and attitude about household waste management than their female counterparts did in Muharraq Governorate. According to [18], women and men may view domestic waste and its disposal differently; they manage waste differently and put different priorities on its disposal.

Moreover, it shows a high public awareness toward household waste management among the people in Muharraq Governorate, which indicated that the society is aware and has the basics to build on in terms of sustainable waste management practices adoption,

In addition, results show that married people have a better attitude toward household waste management than single people do. This is due to the lifestyle of married people and the different sense of responsibilities between the two groups. A study by [19] found that marriage can significantly boost life satisfaction, particularly for those approaching middle-age. This may explain by the positive attitude toward life aspects, including household waste management by married people, particularly those belonging to the 41 - 50 age group who found that they have a significantly high positive behaviour and total awareness than other age groups.

Accordingly, the government should prioritize females and singles to promote knowledge and attitude on effective household waste management in order to promote their attitude. In addition, the age group 21 - 30 must be prioritized to promote behaviour or practice and attitude, and increase total awareness in 
Muharraq Governorate, since the age groups 18 - 20 years and 41 - 50 years have a higher positive behaviour than 21 - 30 years group.

Public awareness can be denoted as the sum of the public: Knowledge, Attitude and Behaviour. The government was strongly recommended to prioritize reduce, reuse and recycle (3Rs) principle to prepare the society for more advanced technologies. People of Muharraq Governorate were found to be aware toward the importance of household waste management and its related issues, which can enable the adoption of any technology in the country. Moreover, total public awareness was found to be significantly correlated with the nationality, in that residence (non-Bahraini) have a higher awareness than Bahraini people, which can be justified by the lower number of non-Bahraini participants as compared to Bahraini, and they might be of a specific occupation mostly e.g. teachers which will have a higher awareness than other groups with mixed educational levels and occupations.

\section{Conflicts of Interest}

The authors declare no conflicts of interest regarding the publication of this paper.

\section{References}

[1] Al-Ansari, M.S. (2012) Improving Solid Waste Management in Gulf Co-Operation Council States: Developing Integrated Plans to Achieve Reduction in Greenhouse Gases. Modern Applied Science, 6, 60-68. https://doi.org/10.5539/mas.v6n2p60

[2] Al-Sabbagh, M.K., Velis, C.A., Wilson, D.C. and Cheeseman, C.R. (2012) Resource Management Performance in Bahrain: A Systematic Analysis of Municipal Waste Management. Secondary Material Flows and Organizational Aspects. Waste Management \& Research, 30, 813-824. https://doi.org/10.1177/0734242X12441962

[3] Eco-Waste (2018) GCC Waste to Energy Report towards a Zero-Waste Society. https://www.ecowaste.ae/ media/GCC-Waste-to-Energy-2018.pdf

[4] United Nations Environment Programme, UNEP (2017) https://wedocs.unep.org/bitstream/handle/20.500.11822/25384/Quarterly\%20Repor t\%20to\%20the $\% 20$ CPR.pdf? sequence $=54$ \&isAllowed $=\mathrm{y}$

[5] Wahid, A. (2015) Importance of Awareness in Solid Waste Management. Envirocivil. https://envirocivil.com/energy/importance-awareness-solid-waste-management/

[6] Hasan, S.E. (2004) Public Awareness Is Key to Successful Waste Management. The Journal of Environmental Science and Health, Part A, Toxic/ Hazardous Substances and Environmental Engineering, 39, 483-492.

https://doi.org/10.1081/ESE-120027539

[7] Central Informatics Organisation (CIO) (2017) http://www.cio.gov.bh/cio eng/default.aspx

[8] Al Seadi, T., Owen, N., Hellström, H. and Kang, H. (2013) Source Separation of MSW. IEA Bioenergy, London, UK.

[9] Chukwunonye, E. and Clive, R. (2012) Analysis of Barriers and Success Factors Affecting the Adoption of Sustainable Management of MSW in Nigeria. Journal of Environmental Management, 103, 9-14.

https://doi.org/10.1016/j.jenvman.2012.02.027 
[10] Korai, M.S., Mahar, R.B. and Uqaili, M.A. (2017) The Feasibility of Municipal Solid Waste for Energy Generation and Its Existing Management Practices in Pakistan. Renewable and Sustainable Energy Reviews, 72, 338-353. https://doi.org/10.1016/j.rser.2017.01.051

[11] Abe, N. and Didham, R. (2007) Measuring Public Awareness and Actions for 3Rs. Warmer Bulletin, 112, 8-10.

[12] Amasuomo, E., Omagbemi, J. and Syed, A. (2015) Analysis of Public Participation in Sustainable Waste Management Practice in Abuja, Nigeria. https://doi.org/10.5296/emsd.v4i1.7269

[13] Umuhire, M.L. and Fang, Q. (2016) Method and Application of Ocean Environmental Awareness Measurement: Lessons Learnt from University Students of China. Marine Pollution Bulletin, 102, 289-294. https://doi.org/10.1016/j.marpolbul.2015.07.067

[14] Han, Z., Duan, Q., Fei, Y., Zeng, D., Shi, G., Li, H. and Hu, M. (2018) Factors that Influence Public Awareness of Domestic Waste Characteristics and Management in Rural Areas. Integrated Environmental Assessment and Management, 14, 395-406. https://doi.org/10.1002/ieam.4033

[15] IUCN (2010) Public Awareness Indicator: Measuring Public Awareness of Biodiversity. Norwegian Ministry of Foreign Affairs.

[16] Kline, R.B. (2015) Principles and Practice of Structural Equation Modeling. Guilford publications, London.

[17] Plavsic, S. (2013) An Investigation of Gender Differences in Pro-Environmental Attitudes and Behaviors. https://opencommons.uconn.edu/srhonors theses/404/

[18] OECD (2018) Waste Disposal \& Equality between Women and Men. https://www.oecd.org/dac/gender-development/1849277.pdf

[19] Grover, S. and Helliwell, J.F. (2014) How's Life at Home? New Evidence on Marriage and the Set Point for Happiness. Journal of Happiness Studies, 20, 373-390. https://doi.org/10.3386/w20794 